\title{
Translation, Cross-Cultural Adaptation, and Validation of the Portuguese Version of the Rotterdam Elderly Pain Observation Scale
}

\author{
Julieta Seixas-Moizes $^{\mathrm{a}} \quad$ Anneke Boerlage $^{\mathrm{b}}$ Érica Negrini Lia ${ }^{\mathrm{a}, \mathrm{c}}$ \\ Lucas Emmanuel Lopes e Santos ${ }^{a}$ Miriane Lucindo Zucoloto ${ }^{d}$ Fabíola Dach ${ }^{e}$ \\ Priscila Colavite Papassidero ${ }^{\mathrm{e}}$ Laís Almeida Leal Wichert-Ana ${ }^{\mathrm{e}}$ Oscar Della Pasqua, $\mathrm{g}$ \\ Marianne Louise Wiesebron ${ }^{\text {h }}$ Tatiana Reis Icuma ${ }^{d}$ Vera Lucia Lanchote ${ }^{i}$ \\ Eduardo Barbosa Coelho ${ }^{j}$ Dick Tibboel ${ }^{b}$ Lauro Wichert-Ana ${ }^{a}$

\begin{abstract}
aDepartment of Radiology, Hematology, and Oncology, University of São Paulo, Ribeirão Preto, Brazil; ${ }^{\text {bDepartment }}$ of Pediatric Surgery, Erasmus Medical Center, Sophia Children's Hospital, Erasmus University, Rotterdam, The

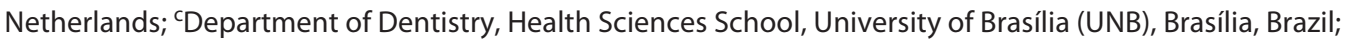

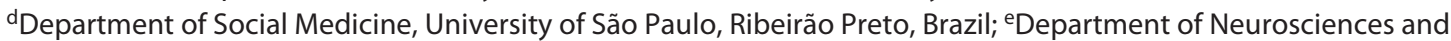
Behavioral Sciences, University of São Paulo, Ribeirão Preto, Brazil; fDivision of Pharmacology, Leiden Academic Centre for Drug Research, University of Leiden, Leiden, The Netherlands; ${ }^{9}$ Clinical Pharmacology \& Therapeutics,

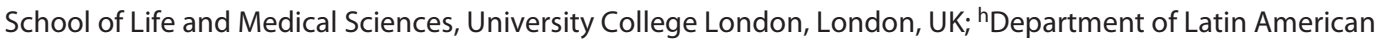
Studies, University of Leiden, Leiden, The Netherlands; 'Department of Clinical Analysis, Food Science and Toxicology, School of Pharmaceutical Sciences of Ribeirão Preto, University of São Paulo, Ribeirão Preto, Brazil; 'Internal Medicine of the Ribeirão Preto Medical School, University of São Paulo, Ribeirão Preto, Brazil
\end{abstract}

\section{Keywords}

Elderly · Pain · Pain assessment · Validation studies

\begin{abstract}
Introduction: This study reports on the translation, cultural adaptation, and validation of a Portuguese version of the Rotterdam Elderly Pain Observation Scale (REPOS), a Dutch scale to assess pain in patients who cannot communicate, with or without dementia. Methods: This is a multicenter study in pain and neurological units involving Brazil (clinical phase) and the Netherlands (training phase). We performed a retrospective cross-sectional, 2-staged analysis, translating and culturally adapting the REPOS to a Portuguese version (REPOS-P) and evaluating its psychometric properties. Eight health professionals were trained to observe patients with
\end{abstract}

karger@karger.com www.karger.com/dee

Karger $\stackrel{\text { ' }}{5}$

GOPEN ACCESS
(C) 2021 The Author(s)

Published by S. Karger AG, Basel

This is an Open Access article licensed under the Creative Commons Attribution-NonCommercial-4.0 International License (CC BY-NC) (http://www.karger.com/Services/OpenAccessLicense), applicable to the online version of the article only. Usage and distribution for commercial purposes requires written permission. low back pain. REPOS consists of 10 behavioral items scored as present or absent after a 2-min observation. The REPOS score of $\geq 3$ in combination with the Numerical Rating Scale (NRS) of $\geq 4$ indicated pain. The Content Validity Index (CVI) in all items and instructions showed CVI values at their maximum. According to the higher correlation coefficient found between NRS and REPOS-P, it may be suggested that there was an adequate convergent validity. Results: The REPOS-P was administered to 80 patients with a mean age of 60 years (SD 11.5). Cronbach's alpha coefficient showed a moderate internal consistency of REPOS-P ( $a=0.62)$, which is compatible with the original study of REPOS. All health professionals reached high levels of interrater agreement within a median of 10 weeks of training, assuring reproducibility. Cohen's kappa was 0.96 (SD 0.03), and the intraclass correlation coefficient was 0.98 (SD 0.02), showing high reliability of REPOS-
Correspondence to:

Lauro Wichert-Ana, lwichert@fmrp.usp.br 
P scores between the trainer (researcher) and the trainees (healthcare professionals). The Pearson correlation coefficient was 0.95 (95\% confidence interval 0.94-0.97), showing a significant correlation between the total scores of REPOS-P and NRS. Conclusion: The REPOS-P was a valuable scale for assessing elderly patients with low back pain by different healthcare professionals. Short application time, ease of use, clear instructions, and the brief training required for application were essential characteristics of REPOS-P.

(c) 2021 The Author(s).

Published by S. Karger AG, Basel

\section{Introduction}

Aging can be defined as a progressive process, with morphological, functional, biochemical, and psychological changes that determine the loss of the individual's ability to adapt to the environment, causing greater vulnerability [1-3].

The rising prevalence of cognitive impairment is an increasing challenge with aging. Populations of Latin America and the Caribbean are aging more rapidly [4]. For these countries, the cognitive impairment prevalence estimates are between $1.9 \%$ and $12.5 \%[4,5]$. In Brazil, the mean prevalence rate of dementia is $7.1 \%$, which is higher than the global prevalence of $5.8 \%$, mainly in those aged 65 years and over [6,7]. In this context, it is important to note that longevity is accompanied not only by an increased risk of diseases related to aging, but many older people present pain as a symptom.

Due to pain, many elderly experience functional limitations and disabilities that may affect their independence and quality of life [8]. Commonly, the elderly are not inclined to report pain to their physician or caretaker as they are convinced that pain is part of aging $[8,9]$. As a result, pain management is often inadequate $[9,10]$. If a person suffers from speech limitations due to aphasia or dementia, the problem becomes even more significant. During possible painful interventions or circumstances, different behavioral reactions are difficult to be interpreted by caretakers or health professionals. In this setting, pain observation can be helpful for the assessment of pain in these people. The Rotterdam Elderly Pain Observation Scale (REPOS) was developed and validated by van Herk et al. [10] for the assessment of pain in nursing home residents with communication difficulties $[11,12]$. It has been validated for chronic and daily pain in noncommunicative adults and cognitively impaired elderly, who are unable to express pain by self-report, hospital patients, and for noncommunicative palliative care patients [12-15].

The Portuguese Version of REPOS
Although an English version is available, the REPOS has not been validated for Portuguese-speaking elderly with speech limitations, so we adopted the translation and adaptation into Portuguese. Portuguese is the fourth most spoken language after Chinese, Spanish, and English [16]. Currently, $>261$ million people speak Portuguese in 5 continents, but indicators suggest that by 2050, Portuguese will have 380 million speakers, making it the third most spoken language in the world [16]. It is essential to consider that experience and culture create the relationship between pain and ethnicity $[17,18]$. Each culture and social group has its complex expressions and language of pain. However, pain and pain control are inner and subjective experiences of the person in pain [19]. The common way of expressing pain by the elderly in many cultures includes paralinguistic expressions (moaning and groaning), language and facial expressions (grimace and arching of the eyebrows), and antalgic positions in cases of severe pain (panic attacks) [17-19]. This study aimed to translate and culturally adapt REPOS into Portuguese (REPOS-P) and to validate it in adult and elderly patients with low back pain.

\section{Materials and Methods}

This study was conducted at the university hospital of our institution, after a 6-month training at the Erasmus Medical Center, Rotterdam, the Netherlands.

Patients and Setting

All patients were admitted to pain and neurological ambulatory care facilities of the university hospital of our institution. The inclusion criteria were as follows: adult patients (over 18 years), not sedated or under mechanical ventilation, and both able to and unable to express pain by self-report. The exclusion criteria included patients with neuropathic diseases and chronic alcoholism.

The study extracted demographic and medical data from medical records and files. The pain diagnosis was classified by the WHO International Classification of Diseases (ICD-10, 2016). Pain medication was stratified according to the WHO analgesic ladder.

Each patient or a responsible relative signed informed consent after explaining the study aims and procedures. The institutional ethical board approved the study of our hospital.

\section{Instruments}

The REPOS is a pain measurement tool for people who cannot communicate. It consists of 10 behaviors (relating to facial expression, motor behavior, and vocalization), which are scored to be absent $(=0)$ or present $(=1)$ after a 2 -min observation period, with a total score ranging from 0 to 10 . A total score of 3 or higher indicates pain. Because other emotions (shame or anger) might influence the strength of the REPOS score, it is always used in combination with the Numerical Rating Scale (NRS) through the as-

Dement Geriatr Cogn Disord Extra 2021;11:314-323 315 
Table 1. Characterization of the experts responsible for evaluating the content of the REPOS-P

\begin{tabular}{llllll}
\hline Expert & Age & Gender & Occupation & Speciality/field of research & $\begin{array}{c}\text { Years in the } \\
\text { profession }\end{array}$ \\
\hline 1 & 53 & Female & Physician/professor & Anesthesiology and pain & 30 \\
2 & 68 & Male & Physician/professor & Neuropsychopharmacology & 23 \\
3 & 39 & Female & Physician/professor & Neurology, headache, and pain & 10 \\
4 & 59 & Female & Psychologist/professor & Psychology and pain & 37 \\
5 & 32 & Female & Psychologist/researcher & Pain and pain measurement & 10 \\
6 & 46 & Female & Dentist/professor & Chronic pain & 24 \\
7 & 31 & Female & Nurse/researcher & Pain and injuries & 8 \\
8 & 55 & Male & Physician/professor & Pain & 30 \\
9 & 53 & Male & Physician/professor & Medical clinic and pain & 32 \\
10 & 35 & Female & Physician & Anesthesiology and pain & 12 \\
\hline
\end{tabular}

REPOS-P, Portuguese version of the Rotterdam Elderly Pain Observation Scale.

sessment of observers. The NRS is a validated instrument rating pain on a scale ranging from $0=$ no pain to $10=$ worst pain. Scores of 4 and higher indicate substantial pain which indicates the need for treatment. The self-reporting of pain may use the NRS, the gold standard, and proxy reporting $[10,11]$. NRS through the assessment of observers represents the health professional opinion of the patients' pain, taking the circumstances into account $[10,11,20]$.

The original validation study of REPOS revealed a significant difference between pain and rest conditions. REPOS largely correlated with another pain assessment instrument, the Pain Assessment in Advanced Dementia (PAINAD) $(r=0.75)$ [20-22]. A pilot implementation studied 15 nurses employed at 8 wards in a nursing home which completed 52 REPOS observations on 24 residents in 6 months [20].

\section{Procedures}

The research procedure consisted of 2 phases: (1) translation and adaptation of the English version of the REPOS into Portuguese and (2) a pilot implementation of the new REPOS-P.

\section{Translation and Cross-Cultural Adaptation}

Translation and cross-cultural adaptation of the REPOS were conducted according to the recommendations of Beaton et al. [23], that is, 3 qualified independent translators, which allowed the identification of different interpretations and resulted in a consensual version of the REPOS-P [24-26]. This consensual version was back-translated into English by 3 different qualified translators unfamiliar with REPOS and not involved with the first translation into Portuguese. A comparison between the back-translated version of REPOS-P and the original English version identified and adjusted discrepancies in translation, resulting in the second version of REPOS-P. These discrepancies and word modifications provided by the multidisciplinary pain experts did not affect the meaning of the words.

A multidisciplinary committee of 10 specialist experts on pain was informed about the purpose of the study and asked to compare the back-translated English version with the original version, taking the concepts of semantic equivalence of the instrument into account. Table 1 gives an overview of the profession of the pain specialists and their years of experience. They were invited to make point modifica- tions and corrections and stimulated to provide suggestions to obtain a clear and functional version of REPOS-P [23-26]. The experts were specialists in pain and related aspects of pain, with an average of 21.6 years $(\mathrm{SD}=10.8)$ of experience in their profession.

The final version of the scale was presented to the experts again with the request to examine each item of REPOS-P on the clarity of the new items, rating them as "unclear," "mostly clear," "clear," or "very clear." Content validity was assessed using the Content Validity Index (CVI). According to experts, the cutoff point adopted for the CVI was $0.78[27,28]$.

\section{Validation of REPOS-P}

A pilot implementation study tested the validity of the final version of REPOS-P. The principal researcher (J.S.M.), a qualified REPOS trainer (Observer \#1), trained 8 healthcare professionals including physician, dentist, biomedical, psychologist, physiotherapist, nurse, and caregiver to perform the REPOS-P observation. They were all female, with a mean age of 32 years (SD 11.6) and an average of 21.6 years (SD 10.8) of experience in their profession. The training program consisted of a theoretical $(5 \mathrm{~h}$ plus training with video exercises) and a practical part. In the preparatory training, a CD-ROM provided by the Erasmus Medical Center, Rotterdam, the Netherlands, offered several examples of all REPOS items [20]. In the practical part, each trainee observed at least 10 patients daily with the qualified trainer and scored the REPOS-P items independently. These observations were used to calculate the interrater agreement (kappa and intraclass correlation coefficient).

\section{Statistical Analyses}

Cohen's kappa was calculated per item, and the intraclass correlation coefficient was calculated on the total score of the instrument, to assess the reliability of REPOS-P between both the trainer and the trainees $[29,30]$. A Cohen's kappa of 0.65 was considered evidence of good interrater reliability [28, 29]. Cronbach's alpha coefficient for the internal consistency of REPOS should preferably be $>0.7[27,29,30]$. The Pearson product-moment correlation coefficient was used to establish the relationship between REPOS-total scores and NRS-proxy scores [20,29]. The data analysis was implemented in R-cran software (version 3.2.2 and the Psych and Irr packages). 
Table 2. Proportions ( $p$ ) of answers "clear" and "very clear" given by the expert's committee and the results of calculation of the CVI of instructions and each item of the REPOS-P

\begin{tabular}{|c|c|c|c|}
\hline Instructions and items of REPOS-P & Instructions and items of REPOS-P & $\begin{array}{l}\text { (p) "very clear" and } \\
\text { "extremely clear" }\end{array}$ & $\mathrm{CVI} *$ \\
\hline Instructions & Instruções & & \\
\hline Part 1 & Parte 1 & 100 & 1.0 \\
\hline Part 2 & Parte 2 & 100 & 1.0 \\
\hline REPOS items & Itens REPOS & & \\
\hline Tense face & Face tensa & 100 & 1.0 \\
\hline Eyes (almost) squeezed & Olhos comprimidos & 100 & 1.0 \\
\hline Raising upper lip & Lábios superiores levantados & 100 & 1.0 \\
\hline Grimace & Careta & 100 & 1.0 \\
\hline Frightened, fearful look & Pavor ou olhar amedrontado & 100 & 1.0 \\
\hline Moving parts of the body & Movimentando partes do corpo & 100 & 1.0 \\
\hline Panicky, panics attacks & Ataques de pânico & 100 & 1.0 \\
\hline Moaning/groaning & Gemidos / Lamentações & 100 & 1.0 \\
\hline Sounds of restlessness/ verbal & Sons de inquietação/Expressões verbais & & \\
\hline expressions & & 100 & 1.0 \\
\hline Breath-holding/faltering respiration & Prender a respiração/Dificuldade em respirar & 90 & 0.9 \\
\hline Final instructions & Instruções finais & 100 & 1.0 \\
\hline Completing the table & Preenchimento da Tabela & & \\
\hline Patient name and observations 1, 2, 3 & Nome do paciente e observações 1, 2, 3 & 100 & 1.0 \\
\hline Observer's name & Nome do observador & 100 & 1.0 \\
\hline Date and time & Data e Horário & 100 & 1.0 \\
\hline Patient's condition & Situação do paciente & 100 & 1.0 \\
\hline Pain medication & Medicação para dor & 100 & 1.0 \\
\hline
\end{tabular}

\section{Results}

\section{Translation and Cross-Cultural Adaptation}

The proportions of answers "clear" and "very clear" and the calculated CVI results according to the responses of the expert's committee about the clarity of the information and items of REPOS-P are presented in Table 2.

The main discrepancies between the original and the back-translated English versions included (a) "Good posture" versus "Suitable posture" (postura adequada); (b) "moving body" versus "psychomotor agitation" (agitação psicomotora); (c) "Moaning/groaning" versus "Moaning/wailing" (gemidos/lamentações); (d) "Change in posture" versus "Change of position" (mudança de posição); and (e) "Eyes (almost) squeezed" versus "Eyes squeezed" (olhos comprimidos). Table 2 shows that almost all of the items and instructions of REPOS-P presented CVI values at their maximum $(100 \% ; 1.0)$.

\section{Validation of REPOS-P}

The study evaluated 80 subjects from the neurology or pain outpatient clinics. Their mean age was 60 years (SD 11.5; age range $29-80$ ), and $66.3 \%$ were female. Table 3 shows the distribution of patients according to demographic and clinical characteristics.

The majority of patients were diagnosed with the musculoskeletal system and connective tissue diseases (47.5\%), followed by neoplasm (13.8\%), and injury, poisoning, and others (12.5\%). Pain treatment with opioids was provided for $43.8 \%$ of patients.

The observations were conducted during a possible painful moment such as physical examination, locomotion such as walking (52.5\%), rest, medical interview, and arterial pressure measurement (47.5\%). Table 4 shows the results of the interobserver agreement according to the observation of healthcare professionals (trainees - observer 2-9) and the principal observer (trainer - observer 1).

The mean kappa was 0.96 (SD 0.03), and the mean ICC was 0.98 (SD 0.02). The item "tense face" was the most 
Table 3. Distribution of the patients according to clinical characteristics

\begin{tabular}{ll}
\hline Clinical characteristics & $N(\%)$ \\
\hline Diseases & \\
Musculoskeletal system and connective tissue & $38(47.5)$ \\
Neoplasms & $11(13.8)$ \\
Injury, poisoning, and certain other consequences of external causes & $10(12.5)$ \\
Nervous system & $6(7.5)$ \\
Skin and subcutaneous tissue & $6(7.5)$ \\
Digestive system & $6(7.5)$ \\
Genitourinary system & $4(5.0)$ \\
Certain infectious and parasitic diseases & $2(2.5)$ \\
Diseases of the ear and mastoid process & $1(1.2)$ \\
Diseases of the eye and adnexa & $1(1.2)$ \\
Comorbidities & \\
Endocrine, nutritional, and metabolic disorders & $16(20.0)$ \\
Circulatory system disorders & $18(22.5)$ \\
Mental and behavior disorders & $19(23.8)$ \\
Use of medication & \\
Opioids & $35(43.8)$ \\
Morphine & $11(13.8)$ \\
Methadone & $10(12.5)$ \\
Tramadol & $18(22.5)$ \\
Fentanil & $2(2.5)$ \\
Others & $70(91.5)$ \\
Anti-epileptics & $24(30.0)$ \\
Antidepressants & $22(27.5)$ \\
Conzodiazepines & $17(21.2)$ \\
\hline
\end{tabular}

Table 4. Interobserver agreement between trainees (observers 2-9) and trainer (observer 1, not in table) obtained by Cohen's kappa and ICC with their corresponding $\mathrm{Cl} 95 \%$

\begin{tabular}{lllll}
\hline Observer & Kappa & Cl 95\% & ICC & Cl95\% \\
\hline 2 & 0.95 & $(0.88 ; 1.00)$ & 0.98 & $(0.93 ; 0.99)$ \\
3 & 0.97 & $(0.92 ; 1.00)$ & 0.99 & $(0.95 ; 0.99)$ \\
4 & 1.00 & $(1.00 ; 1.00)$ & 1.00 & $(1.00 ; 1.00)$ \\
5 & 0.95 & $(0.88 ; 1.00)$ & 0.96 & $(0.85 ; 0.99)$ \\
6 & 0.92 & $(0.84 ; 1.00)$ & 0.99 & $(0.95 ; 0.99)$ \\
7 & 0.95 & $(0.87 ; 1.00)$ & 0.94 & $(0.78 ; 0.98)$ \\
8 & 0.95 & $(0.87 ; 1.00)$ & 0.97 & $(0.90 ; 0.99)$ \\
9 & 1.00 & $(1.00 ; 1.00)$ & 1.00 & $(1.00 ; 1.00)$ \\
\hline Mean & 0.96 & & 0.98 & \\
\hline
\end{tabular}

ICC, intraclass correlation coefficient; CI 95\%, 95\% confidence intervals.

observed, while "breath-holding/faltering respiration" was the least observed.

Cronbach's alpha coefficient for the internal consistency of REPOS-P was $\alpha=0.62$. The correlation between REPOS-P and the NRS proxy obtained by the Pearson correlation coefficient was 0.95 (95\% confidence interval $=0.94-0.97$ ).

\section{The Final Version of REPOS-P}

The final version of the REPOS-P form is available in Figures 1-3. Figures 1-3 show the original REPOS template incorporating the translation to Portuguese.

\section{Discussion}

This study reports on the translation, cultural adaptation, and validation of a Portuguese version of REPOS and the first study to offer in Portuguese a scale to assess pain in patients who cannot communicate, with or without dementia. This scale has proved to be helpful in routine care in hospitals due to the short administration time, ease of use, and clear instructions. REPOS-P may provide an essential tool for Portuguese-speaking countries.

In the first phase of this study, the translation process of the items and instructions presented a consensus backtranslated version that confirmed good similarity and semantic equivalence between the original and REPOS-P. 


\section{Escala de Observação de Dor em Idosos Rotterdam}

\section{(REPOS-P)}

\section{Instruções \\ Definição de comportamentos}

Cada item da REPOS representa um comportamento especifico ou uma certa reação. A REPOS não gradua a intensidade do comportamento, mas a sua ocorrência, que deve ser assinalada com sim ou não.

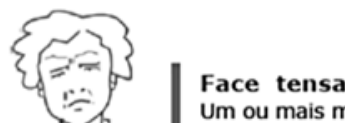

Um ou mais músculos faciais estão contraidos (não relaxados). NÃO pontuar enquanto o cliente estiver falando.

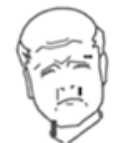

Olhos comprimidos

Olhos fechados com força ou apertados. Não pontue se o paciente estiver piscando ou de olhos fechados sem comprimi-los.

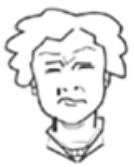

Lábios superiors levantados

O lábio superior está sendo puxado para cima, encurtando a distância entre o lábio superior e o nariz; os sulcos nasolabiais estão mais pronunciados, as narinas estấo abertas e dilatadas.

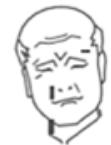

\section{Careta}

Deve ser assinalada como presente somente quando as três expressões faciais seguintes ocorrerem juntas:

1) Sobrancelhas juntas e direcionadas para baixo, com rugas de expressão entre as sobrancelhas.

2) Olhos apertados com força ou contraídos.

3) Sulcos nasolabiais mais pronunciados do que o habitual e puxados para as laterais do rosto.

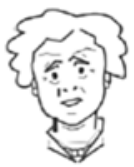

\section{Pavor ou olhar amedrontado}

Olhos arregalados e as laterais internas das sobrancelhas levemente erguidas e aproximadas.

Movimentando partes do corpo

Cada movimento que indique resistência ou tentativa de proteger uma parte (dolorida) do corpo. Estão incluidos ai movimentos como mudar de posição na cadeira para aliviar a pressão nas nádegas ou segurar a cabeça. NÃO assinale quando o movimento ou a ação for funcional, como afastar os cabelos da frente do rosto ou erguer os braços para tirar peças de roupa.

Ataques de pânico

Uma manifestação de intensa ansiedade associada por agitação psicomotora ou de grande resistência.

Pode ocorrer com:

- Expressão amedrontada caracterizada por olhos arregalados e laterais internas das sobrancelhas levemente erguidas e aproximadas; e/ou

- Gritos intensos ou expressões verbais de dor, tais como "ai" ou "você está me machucando".

Gemidos / lamentaçöes

Sons monótonos e lamentosos.

Sons de inquietação / expressőes verbais

Gritos intensos súbitos ou persistentes, ou expressões verbais de dor, tais como "ai" ou "você está me machucando".

Prender a respiração / Dificuldade de respirar

Respiração brevemente interrompida, ofegante.

Fig. 1. The REPOS-P of the REPOS, Page 1. REPOS, Rotterdam Elderly Pain Observation Scale; REPOS-P, Portuguese version. 
Escala de Observação de Dor em Idosos de Rotterdam (REPOS-P)

Favor observar por dois minutos e marcar nos quadrados se o comportamento específico descrito

esteve presente durante a observação. A seguir, some todos os comportamentos

assinalados para obter o escore total da REPOS.

\section{NOME DO CLIENTE}

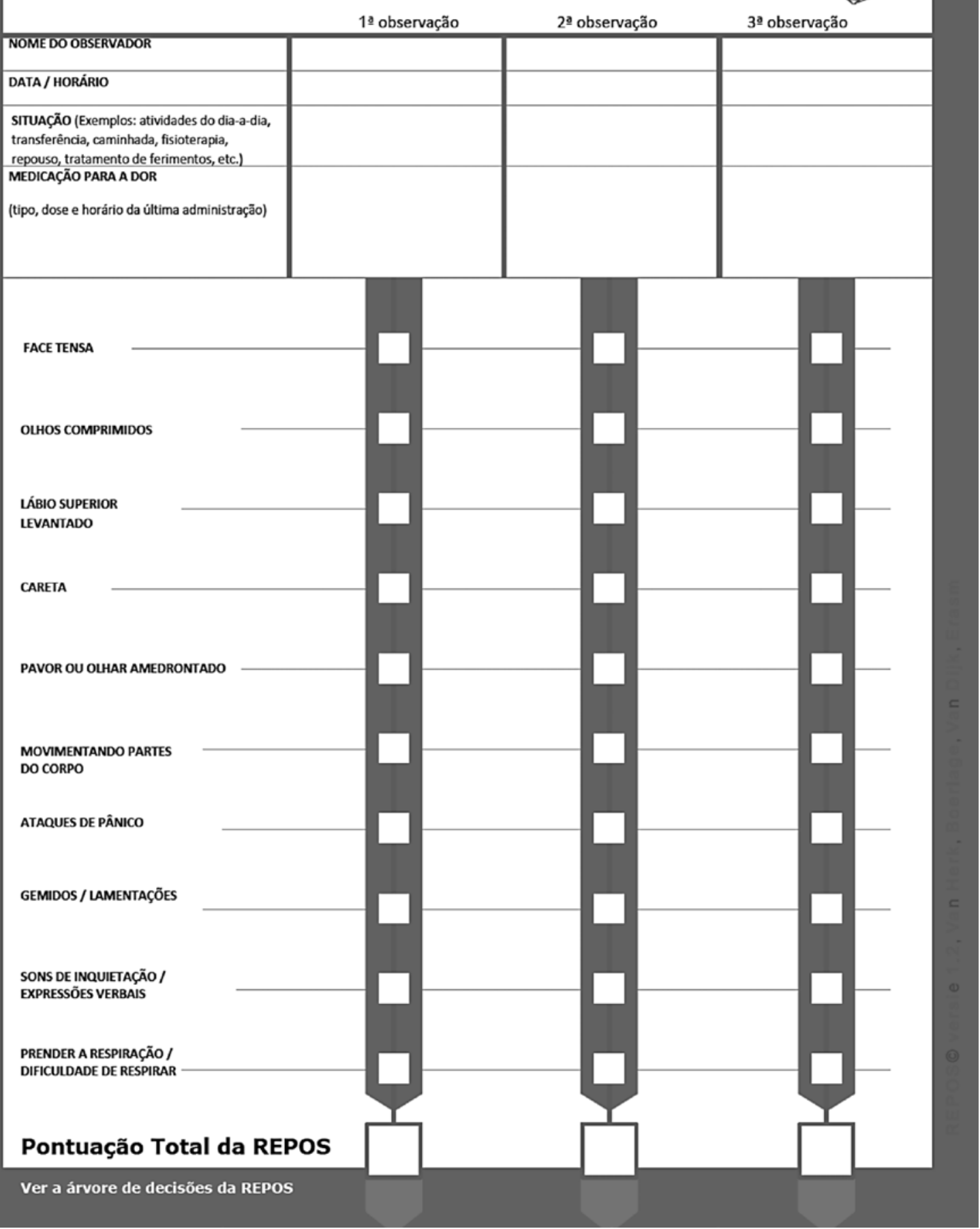

Fig. 2. The REPOS-P of the REPOS, Page 2. REPOS, Rotterdam Elderly Pain Observation Scale; REPOS-P, Portuguese version. 


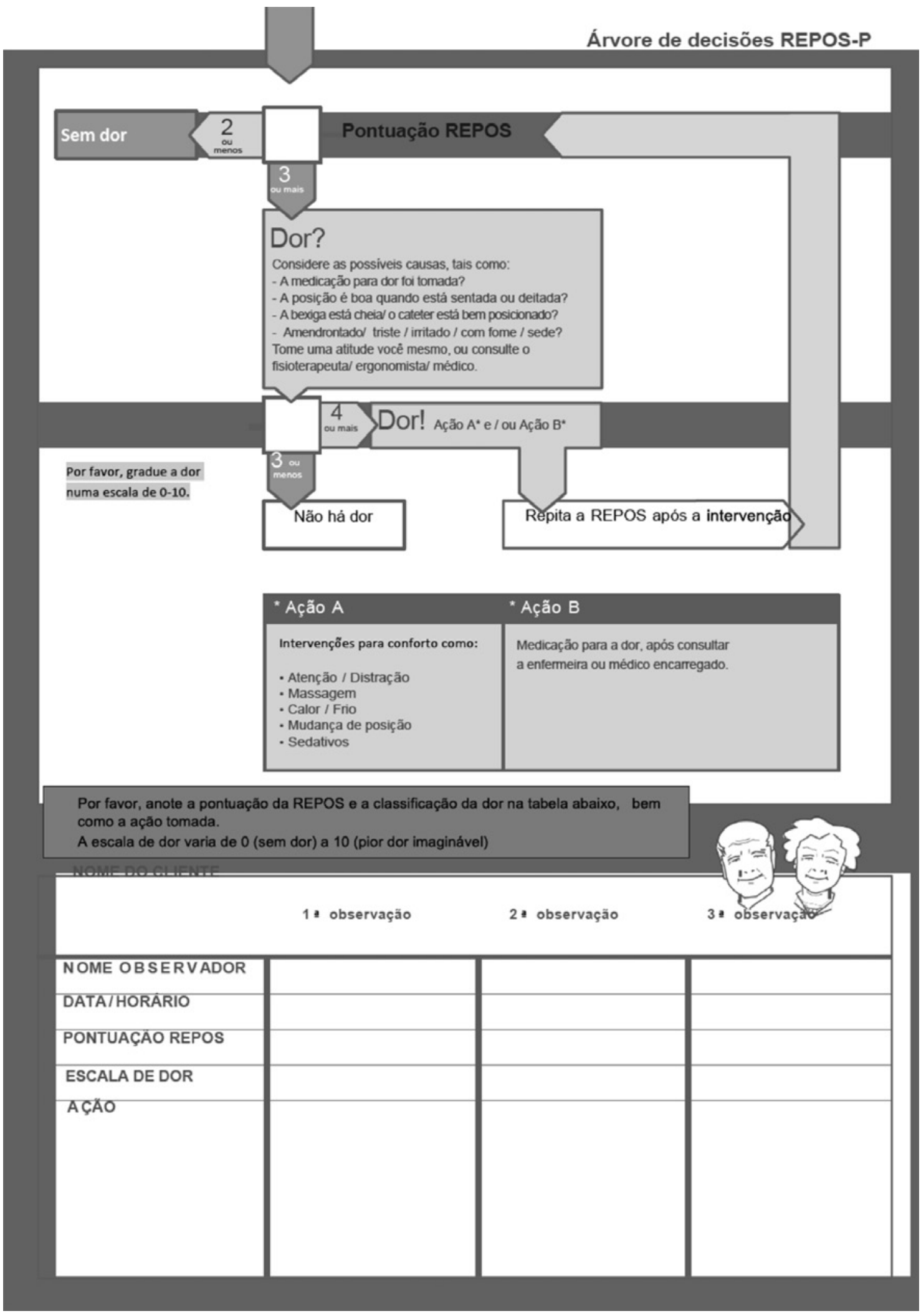

Fig. 3. The REPOS-P of the REPOS, Page 3. REPOS, Rotterdam Elderly Pain Observation Scale; REPOS-P, Portuguese version. 
According to the experts' committee, REPOS-P was adequate and clear to the target population, which the CVI values for all items can reinforce.

The training was necessary for the reliable administration of the pain observation tool. The availability of an instruction chart increases interrater reliability, while the decision tree helps evaluate the observation and decide if an intervention is necessary. For training in the Portuguese language, those interested can contact the corresponding author. For the English version of REPOS, there is an emodule REPOS available at www.comfortassessment.nl/reposscale/index.php $[17,20]$. In the second phase, 8 observers were invited for reliability analysis of interrater measures, with the beneficial interest to validate an easy-to-use scale in clinical and hospital settings [22, 29, 30].

The observation of the patients reflected the expected conditions in elderly patients, that is, musculoskeletal system and connective tissue diseases, and neoplasm, injury, or poisoning. The item tense face was the most observed, while breath-holding/faltering respiration was the item that appeared the least. The REPOS-P presented versatility of use in the studied population, despite the heterogeneous clinical settings and a wide age range of patients. Rhodee van Herk et al. (2009) evaluated 174 patients, mostly female, with a median age of 82 years (ranging from 73 to 87 years). The present study was equivalent concerning pain diagnoses, most patients with musculoskeletal disorders, but we had a more significant number of neoplasms, $13.8 \%$ versus $2 \%$ [20].

The results of the interobserver agreement, according to the observation of healthcare professionals (trainees observer 2-9) and the principal observer (trainer - observer 1), showed that the mean kappa and the mean ICC were adequate (Table 4). These results are in line with the original pilot implementation project of REPOS [20].

According to the high correlation coefficient found between NRS and REPOS-P, it may be suggested that there was an adequate convergent validity. The result in the REPOS study showed that the correlation between REPOS and NRS was small to medium [27-29]. The internal consistency of REPOS-P showed acceptable content reliability ( $\alpha$ ) of 0.62 , being compatible with the original study of REPOS and indicating a moderate internal consistency $[27,28]$.

This study has some limitations, such as the small size of the sample and the number of trained professionals. Further studies should assess the psychometric properties of REPOS-P in representative samples of healthcare professionals observing patients with distinct health conditions, not only in low back pain.

\section{Conclusions}

REPOS-P showed adequate reliability and validity in the present study. Different health professionals can use it to assess pain in adults and the elderly with verbal communication problems.

\section{Statement of Ethics}

The Ethics Committee of the Clinical Hospital of the Ribeirão Preto Medical School, the University of São Paulo, Brazil, approved this study, approval No. 14114/2014. This study was conducted ethically under the Declaration of Helsinki. All participants signed the written informed consent to participate in the study.

\section{Conflict of Interest Statement}

The authors have no conflicts of interest to declare.

\section{Funding Sources}

The authors gratefully acknowledge financial support from (a) Grant No. 049/2013 (AUXPE No. 2880/2013) from CAPES/NUFFIC, Brazil Netherlands International Cooperation (LWA, ODP), and (b) Grant No. 2013/25.987-2 (LWA) and Grant No. 2015/50089-3 (LWA, DT) from the State of São Paulo Research Foundation - FAPESP.

\section{Author Contributions}

Julieta Seixas-Moizes, Erica Negrini Lia, Eduardo Barbosa Coelho, and Lauro Wichert-Ana contributed to conception and design of the study. Julieta Seixas-Moizes, Miriane Lucindo Zucoloto, Laís Almeida Leal Wichert-Ana, and Tatiana Reis Icuma contributed to data acquisition, analysis, and interpretation. Julieta Seixas-Moizes, Anneke Boerlage, Lucas Emmanuel Lopes e Santos, Fabíola Dach, Priscila Colavite Papassidero, Oscar Della Pasqua, Marianne Louise Wiesebron, Vera Lucia Lanchote, Dick Tibboel, and Lauro Wichert-Ana drafted and revised the critical intellectual content. Julieta Seixas-Moizes, Anneke Boerlage, Oscar Della Pasqua, Dick Tibboel, and Lauro Wichert-Ana provided final approval of the manuscript. Julieta Seixas-Moizes and Lauro WichertAna took accountability for the accuracy or integrity of the work.

\section{Data Availability Statement}

The data that support the findings of this study can be acquired from the corresponding author upon reasonable request. 


\section{References}

1 Hadjistavropoulos T. Self-management of pain in older persons: helping people help themselves. Pain Med. 2012 Apr;13(Suppl 2): S67-71.

2 Hadjistavropoulos T, Fitzgerald TD, Marchildon GP. Practice guidelines for assessing pain in older persons with dementia residing in long-term care facilities. Physiother Can. 2010 Apr;62(2):104-13.

3 Hadjistavropoulos T, Herr K, Turk DC, Fine PG, Dworkin RH, Helme R, et al. An interdisciplinary expert consensus statement on assessment of pain in older persons. Clin J Pain. 2007 Jan;23(1 Suppl):S1-43.

4 Ashby-Mitchell K, Jagger C, Fouweather T, Anstey KJ. Life expectancy with and without cognitive impairment in seven Latin American and Caribbean countries. PLoS One. 2015 Mar;10(3):e0121867.

5 Peacock S, Patel S. Cultural Influences on Pain. Rev Pain. 2008;1(2):6-9.

6 Burlá C, Camarano AA, Kanso S, Fernandes D, Nunes R. Panorama prospectivo das demências no Brasil: um enfoque demográfico. Cien Saude Colet. 2013;18(10):2949-56.

7 Thé KB, Gazoni FM, Cherpak GL, Lorenzet IC, Santos LAD, Nardes EM, et al. Pain assessment in elderly with dementia: Brazilian validation of the PACSLAC scale. Einstein. 2016 Apr;14(2):152-7.

8 Jones SL, Hadjistavropoulos HD, Janzen JA, Hadjistavropoulos T. The relation of pain and caregiver burden in informal older adult caregivers. Pain Med. 2011 Jan;12(1):51-8.

9 Gagliese L, Katz L, Gibson M, Clark AJ, Lussier D, Gordon A, et al. A brief educational intervention about pain and aging for older members of the community and health care workers. J Pain. 2012 Sep;13(9):849-56.

10 van Herk R, Boerlage AA, van Dijk M, Baar FP, Tibboel D, de Wit R. Pain management in Dutch nursing homes leaves much to be desired. Pain Manag Nurs. 2009 Mar; 10(1):329.
11 Boerlage AA, van Dijk M, Stronks DL, de Wit $\mathrm{R}$, van der Rijt CC. Pain prevalence and characteristics in three Dutch residential homes. Eur J Pain. 2008 Oct;12(7):910-6.

12 Boerlage AA, Valkenburg AJ, Scherder EJA, Steenhof G, Effing P, Tibboel D, et al. Prevalence of pain in institutionalized adults with intellectual disabilities: a cross-sectional approach. Res Dev Disabil. 2013 Aug;34(8): 2399-406.

13 van Herk R, van Dijk M, Baar FP, Tibboel D, de Wit R. Observation scales for pain assessment in older adults with cognitive impairments or communication difficulties. Nurs Res. 2007 Jan-Feb;56(1):34-43.

14 Masman $\mathrm{AD}$, van Dijk M, van Rosmalen J, Baar FPM, Tibboel D, Boerlage AA. The Rotterdam Elderly Pain Observation Scale (REPOS) is reliable and valid for non-communicative end-of-life patients. BMC Palliat Care. 2018 Feb;17(1):34

15 Boerlage AA, van Rosmalen J, Cheuk-AlamBalrak JM, Goudzwaard JA, Tibboel D, van Dijk M. Validation of the rotterdam elderly pain observation scale in the hospital setting. Pain Pract. 2019 Apr;19(4):407-17.

16 Camões I. Uma língua para o mundo [Internet]. Instituto Camões. [cited 2019 May 6]. Available from: https://www.institutocamoes.pt/images/cultura_externa/diptico_ dlp16.pdf.

17 Diller A. Cross-cultural pain semantics. Pain. 1980 Aug;9(1):9-26.

18 Campbell CM, Edwards RR. Ethnic differences in pain and pain management. Pain Manag. 2012;2(3):219-30.

19 Dellaroza MSG, Pimenta CAde M, Duarte YA, Lebrão ML. [Chronic pain among elderly residents in São Paulo, Brazil: prevalence, characteristics, and association with functional capacity and mobility (SABE Study)]. Cad Saude Publica. 2013 Feb;29(2):325-34.
20 van Herk R, van Dijk M, Tibboel D, Baar FPM, de Wit R. The Rotterdam Elderly Pain Observation Scale (REPOS): a new behavioral pain scale for non-communicative adults and cognitively impaired elderly persons. J Pain Manag. 2009;1(4):367-78.

21 Warden V, Hurley AC, Volicer L. Development and psychometric evaluation of the Pain Assessment in Advanced Dementia (PAINAD) scale. J Am Med Dir Assoc. 2003 Jan; 4(1):9-15.

22 Pinto MC, Minson FP, Lopes AC, Laselva CR Cultural adaptation and reproducibility validation of the Brazilian Portuguese version of the Pain Assessment in Advanced Dementia (PAINAD-Brazil) scale in non-verbal adult patients. Einstein. 2015 Jan;13(1):14-9.

23 Beaton DE, Bombardier C, Guillemin F, Ferraz MB. Guidelines for the process of crosscultural adaptation of self-report measures. Spine. 2000 Dec;25(24):3186-91.

24 Walter SD, Altman DG. Practical statistics for medical research. Biometrics. 1992;48(2):656.

25 Altman DG. Practical statistics for medical research. CRC Press; 1990.

26 Guillemin F, Bombardier C, Beaton D. Crosscultural adaptation of health-related quality of life measures: literature review and proposed guidelines. J Clin Epidemiol. 1993 Dec; 46(12):1417-32.

27 Wynd CA, Schmidt B, Schaefer MA. Two quantitative approaches for estimating content validity. West J Nurs Res. 2003 Aug; 25(5):508-18.

28 Bartko JJ. The intraclass correlation coefficient as a measure of reliability. Psychol Rep. 1966;19(1):3-11.

29 Cohen J. Weighted kappa: nominal scale agreement provision for scaled disagreement or partial credit. Psychol Bull. 1968;70(4): 213-20.

30 Gloth FM 3rd. Geriatric pain. Factors that limit pain relief and increase complications. Geriatrics. 2000;55(10):46-8, 51-4. 